\title{
БУХГАЛТЕРСКИЙ УЧЕТ ОБЕСПЕЧЕНИЯ ИСПОЛНЕНИЯ КОНТРАКТНЫХ ОБЯЗАТЕЛЬСТВ В РОССИИ
}

\author{
(C) 2021 Петрова О.А. \\ старший преподаватель Департамента бизнес-аналитики \\ Финансовый университет при Правительстве Российской Федерации, Россия, Москва \\ E-mail: olga1717@bk.ru
}

Один из основополагающих принципов составления финансовой отчетности - отражение достоверной информации о финансовом положении организации. Следовательно, вопросы бухгалтерского учета любого вида обязательств чрезвычайно важны. В данной статье уделим внимание вопросу учета контрактных обязательств.

Ключевые слова: учет, анализ, аудит, налогообложение, контрактное обязательство, залог

В современной мировой экономике расчеты между экономическими субъектами практически всегда сопровождаются возникновением таких категорий бухгалтерского учета, как кредиторская задолженность у покупателя, и дебиторская задолженность у продавца товаров либо услуг. Это является следствием существующей системы расчетов между организациями, при которой зачастую имеется разрыв времени платежа с моментом перехода права собственности на товары, работы и услуги. Максимальный срок такого разрыва всегда фиксируется в заключаемом между двумя экономическими субъектами контракте, в части условий и сроков платежей по договору.

Однако в современных условиях, характеризующихся нестабильной экономической обстановкой во всем мире, во много раз возрастает риск нарушения сроков оплаты по договорам с контрагентами. Это в свою очередь может оказать крайне негативное влияние на финансовое состояние хозяйствующего субъекта, вызывать кассовые разрывы и порождать цепочки неплатежей. Так, по данным Росстата, просроченная кредиторская задолженность организаций в России выросла за период январь - июль 2020 г. на 21,38 процентов и в абсолютном выражении на конец 2 квартала составила 4,28 трлн. рублей, что выше показателя за аналогичный период 2019 г. на 22 процента [6].

С учетом вышеуказанных рисков, экономическим субъектам видится целесообразным применять практику предотвращения возникновения безнадежных долгов уже на стадии подготовки договора с контрагентом, а именно включать в контракты предусмотренные зако- нодательством Российской Федерации способы обеспечения исполнения договорных обязательств, которые будут выступать гарантией соблюдения финансовых интересов продавца, а также гарантией исполнения договора для покупателя.

Основным нормативно-правовым актом, регулирующим контрактные взаимоотношения, выступает ГК РФ (ст. 329) [1].

Одним из наиболее часто используемых методов из данного списка является залог. Сущность залога заключается в том, что кредитор по обеспеченному залогом обязательству (залогодержатель) имеет право в случае неисполнения должником этого обязательства получить удовлетворение из стоимости заложенного имущества преимущественно перед другими кредиторами лица, которому принадлежит это имущество (залогодателя). Применение залога регулируется статьей 334 ГК РФ [1].

С точки зрения современного российского бухгалтерского учета, поступления в организацию в виде залога не признаются в качестве дохода организации согласно п. 3 ПБУ 9/99 «Доходы организации» [2]. Заложенное имущество залогодателя остается в его собственности и продолжает учитываться на его балансе как актив. При этом в аналитическом учете, организованном к синтетическому счету, на котором числится соответствующий вид имущества, должна найти отражение информация о том, что данное имущество находится в залоге. Поэтому планом счетов бухгалтерского учета для отражения операций, связанных с обеспечением обязательств, предусмотрены забалансовые счета 008 «Обеспечение обязательств и платежей полученные» 
и 009 «Обеспечение обязательств и платежей выданные».

Типичной бухгалтерской проводкой при передаче объекта основных средств в залог является дебет счета 01 «Основные средства» субсчет «Основные средства, выданные в залог» - кредит счета 01. При этом в учете залогодателя также делается запись, отражающая договорную стоимость выданного обязательства по дебету забалансового счета 009 «Обеспечения обязательств и платежей выданные».

Другим схожим гарантийным инструментом, который предприятие вправе требовать у контрагента, является задаток. Согласно статье 380 ГК РФ задатком признается денежная сумма, выдаваемая одной из договаривающихся сторон в счет причитающихся с нее по договору платежей другой стороне, в доказательство заключения договора и в обеспечение его исполнения [1]. Согласно п. 3 ПБУ 9/99 «Доходы организации» сумма задатка полученного также не признается в составе доходов организации [2].

В зависимости от вида договора, по которому выдается задаток, его сумму учитывается на счете 62 «Расчеты с покупателями и заказчиками», либо на счете 76 «Расчеты с разными дебиторами и кредиторами». К этим счетам организации целесообразно открыть субсчет «Расчеты по полученным задаткам». Поскольку задаток является способом обеспечения исполнения обязательств по договору, сумму задатка нужно учесть за балансом. Для этого так же, как и в предыдущем случае, используется счет 008 «Обеспечения обязательств и платежей полученные». Таким образом, типичные проводки при учете полученного в счет обеспечения исполнения обязательств по договору задатка - дебет счета 51 (50) «Расчетные счета» («Касса») кредит счета 62 (76) «Расчеты с покупателями и заказчиками» («Расчеты с разными дебиторами и кредиторами») субсчет «Расчеты по полученным задаткам». При этом также сумму задатка необходимо отразить за балансом по дебету счета 008.

После того как условия договора будут выполнены, обеспечительная функция задатка прекращается - он засчитывается в счет платежей, причитающихся по договору. Это является основанием для его списания с забалансового учета записью по кредиту счета 008 «Обеспече- ния обязательств и платежей полученные».

Однако если организация, получившая задаток, не исполнила договорные обязательства по своей вине, она обязана вернуть контрагенту задаток в двойном размере, сверх того, возместить убытки в части, превышающей полученную ранее сумму задатка (ст. 381 ГК РФ) [1].

Однако по вопросу необходимости отражения банковских гарантий в бухгалтерском учете на забалансовых счетах существует определенная двойственность взглядов. Противники отражения банковских гарантий в учете принципала считают, что гарантию принципал получает не для себя, а для бенефициара, при этом гарантом выступает не принципал, а сторонняя организация - банк либо уполномоченное финансовое учреждение. Следовательно, отсутствуют основания для применения принципалом забалансовых счетов [5, с.146].

Тем не менее, следует учитывать, что одним из требований ПБУ $1 / 2008$ «Учетная политика организации» к отчетности является требование полноты отражения фактов хозяйственной жизни. Отражение данных фактов хозяйственной жизни на забалансовых счетах позволяет учесть факт смены кредитора при неисполнении обязательства принципалом (исполнение гарантом своих обязательств перед бенефициаром, и одновременное превращение гаранта в кредитора по отношению к принципалу), что повышает качество составляемой финансовой отчетности. Аналогично учету банковских гарантий ведется учет операций, связанных с договорами поручительства.

Таким образом, законодательством России предусмотрен ряд мер, гарантирующих исполнение договорных обязательств контрагентами и предупреждающих возникновение безнадежных долгов на балансе организаций, при этом наиболее предпочтительным, с точки зрения автора, является получение банковских гарантий, либо залога. Система бухгалтерского учета для большинства обеспечительных мер построена на использовании забалансовых счетов 008 «Обеспечение обязательств и платежей полученные» и 009 «Обеспечение обязательств и платежей выданные», что выделяет их из других категорий бухгалтерского учета. 


\section{Библиографический список}

1. Гражданский Кодекс Российской Федерации. Часть 1. Принят Государственной Думой 21 октября 1994 года № 51-ФЗ от 30 ноября 1994 г. (в ред. от 31 июля 2020 г.) // КонсультантПлюс: справочно-правовая система

2. Приказ Минфина России от 06.05.1999 № 32н (в ред. от 06.04.2015) «Об утверждении Положения по бухгалтерскому учету «Доходы организации» ПБУ 9/99» // КонсультантПлюс: справочно-правовая система

3. Приказ Минфина России от 06.10.2008 № 106н (в ред. от 07.02.2020) «Об утверждении положений по бухгалтерскому учету» (вместе с «Положением по бухгалтерскому учету «Учетная политика организации» (ПБУ 1/2008)» // КонсультантПлюс: справочно-правовая система

4. Мельникова Л.А. Бухгалтерский учет финансовых резервов и оценочных обязательств: монография / Л.А. Мельникова, А. М.Петров.- Москва: Вузовский учебник: ИНФРА-М, 2019. - 96 с. - (Научная книга).ISBN 978-5-9558-0402-6.- Текст: электронный.- URL: https://znanium.com/catalog/product/1002090 (дата обращения: 02.10.2020).- Режим доступа: по подписке.

5. Аксенова Е.И. Банковская гарантия в контрактной системе как вид независимой гарантии // Colloquiumjournal. 2020. № 3 (55). - с. 146-147

6. ффициальный сайт Федеральной службы государственной статистики (Росстат) URL: https://rosstat.gov.ru (дата обращения: 12.10.2020) 